Research Article

\title{
Peningkatan Hasil Belajar Biologi dengan Model Pembelajaran Kooperatif Tipe Inside Outside Circle pada Peserta Didik Kelas VII B Semester Genap SMP Negeri 1 Tamiang Layang
}

\author{
Listin Ngantung ${ }^{1 *}$ \\ ${ }^{1}$ SMP Negeri 1 Tamiang Layang, Kalimantan Tengah, Indonesia \\ *emal: listintlyg@gmail.com
}

Kata Kuci:

Hasil Belajar Biologi

Inside-Outside Circle

Model Pembelajaran

Kooperatif

Submitted: $29 / 08 / 2020$

Revised: 09/10/2020

Accepted: 01/12/2020

\begin{abstract}
Abstrak. Model pembelajaran kooperatif (Cooperative Learning), yang pada prinsipnya merupakan proses pembelajaran berbasis kerja sama antar peserta didik dan antar komponen-komponen lain di sekolah. Dalam upaya peningkatan Hasil Belajar Biologi dengan model pembelajaran kooperatif tipe Inside-Outside Circle dapat meningkatkan hasil belajar biologi peserta didik kelas VII B SMP Negeri 1 Tamiang Layang telah dilaksanakan dan model pembelajaran kooperatif tipe Insideotside Circle meningkatkan dapat menningkatkan hasil belajar biologi pada materi Klasifikasi Makhluk Hidup. Telah di praktekkan terhadap Peserta didik dalam pembelajaran biologi dengan model pembelajaran kooperatif tipe Inside-outside Circle memperoleh rerata hasil belajar lebih baik yaitu 68,35 pada siklus I dan 77,21 pada siklus II. Secara Implikasi Teoritis dapat memperluas pengetahuan mengenai faktor-faktor yang mempengaruhi hasil belajar peserta didik. Penggunaan model pembelajaran harus disesuaikan dengan karakteristik materi pembelajaran yang akan disampaikan. Implikasi Praktis bagi Guru dapat menggunakan model pembelajaran kooperatif tipe Inside-outside Circle untuk meningkatkan hasil belajar biologi khususnya pada materi Klasifikasi Makhluk Hidup, Dalam pembelajaran, guru seharusnya memperhatikan aktivitas peserta didik secara menyeluruh. Penggunaan model pembelajaran kooperatif tipe Inside-outside circle sangat efektif untuk semua mata pelajaran dan untuk semua tingkatan usia didik.
\end{abstract}

\section{PENDAHULUAN}

Pelaksanaan pembelajaran yang diamanatkan dalam sistem pendidikan nasional bertujuan agar peserta didik dapat belajar untuk beriman dan bertaqwa kepada Tuhan Yang Maha Esa, belajar untuk memahami dan menghayati, belajar untuk hidup bersama dan berguna bagi orang lain, belajar untuk membangun dan menemukan jati diri melalui proses belajar yang aktif, kreatif, efektif, dan menyenangkan (Depdiknas, 2007:5). Guna mewujudkan hal tersebut, maka pembelajaran di sekolah harus mampu memberdayakan peserta didik untuk membangun pengetahuan sendiri dengan difasilitasi oleh guru. 
Undang-Undang Pendidikan Nomor 20 Tahun 2003 menyebutkan bahwa Pendidikan adalah usaha sadar dan terencana untuk mewujudkan suasana belajar dan proses pembelajaran agar peserta didik secara aktif mengembangkan potensi dirinya untuk memiliki kekuatan spiritual keagamaan, pengendalian diri, kepribadian, kecerdasan, akhlak mulia, serta keterampilan yang diperlukan dirinya, masyarakat, bangsa, dan negara. Sementara itu dalam KTSP 2006 dinyatakan bahwa salah satu tujuan pembelajaran IImu Pengetahuan Alam atau sains adalah untuk membantu peserta didik agar mampu menguasai pengetahuan tentang keteraturan sains. Pengetahuan tersebut diperoleh melalui proses ilmiah sehingga peserta didik memiliki sikap ilmiah yang dapat digunakan untuk memecahkan masalah dalam kehidupan sehari-hari. Hal ini relevan dengan hakikat pembelajaran sains yang mengacu pada tiga aspek yaitu produk, proses, dan sikap.

Mengajarkan ilmu kepada peserta didik dikatakan baik kalau memenuhi kriteria, yaitu sesuai dengan hakikat ilmu serta dengan pengetahuan tentang bagaimana peserta didik belajar. IPA sebagai ilmu juga harus diajarkan sesuai dengan hakikat IPA dan teori belajar yang mendasari pembelajaran IPA itu. Adapun hakikat IPA terdiri atas tiga komponen, yaitu (1) sikap ilmiah, (2) proses ilmiah, dan (3) produk ilmiah.

Hasil belajar di SMP Negeri 1 Tamiang Layang, khususnya untuk mata pelajaran IPA tahun pelajaran 2014/2015 masih di bawah KKM (Kriteria Ketuntasan Minimal) 65 yaitu diperoleh rerata kelas 60 . Hal ini diprediksi dipengaruhi oleh beberapa faktor diantaranya faktor guru dan peserta didik.

Pertama, ditinjau dari faktor gurunya. Pembelajaran IPA (biologi) di SMP Negeri 1
Sambungmacan cenderung bersifat deklaratif. Akibatnya, peserta didik menjadi pasif, pembelajaran membosankan dan tidak menarik. Hal ini tidak sesuai dengan hakekat pendidikan IPA, yang tidak hanya mengutamakan produk atau hasil tetapi juga pada proses pembelajaran dan sikap dalam pembelajaran. Selain itu, meski secara keilmuan terjadi perubahanperubahan (perkembangan) dalam pembelajaran IPA, namun kenyataannya pembelajaran IPA (biologi) di SMP Negeri 1 Tamiang Layang masih cenderung berorientasi pada guru (teacher centered). Guru masih menekankan pada perannya sebagai penyampai materi pelajaran (transformator), sehingga hasil belajar yang dicapai peserta didik dalam kegiatan belajar mengajar belum sesuai yang diharapkan atau masih di bawah KKM.

Kedua, ditinjau dari faktor peserta didiknya. Pembelajaran biologi menuntut adanya peran aktif peserta didik, karena salah satu karakteristik biologi adalah adanya proses ilmiah yang diperoleh melalui kegiatan penyelidikan. Peserta didik di SMP Negeri 1 Tamiang Layang belum dapat berpartisipasi aktif dalam proses belajar mengajar. Peserta didik dalam pembelajaran masih bersifat individual, pasif, dan kurang bergairah. Kondisi ini dapat dilihat dari kecenderungan peserta didik terhadap beberapa hal, antara lain: peserta didik hanya menerima informasi/materi dari guru secara pasif, peserta didik kurang menyenangi mata pelajaran biologi dan lebih menyenangi pembelajaran yang bersifat fisik (olahraga), minat belajar rendah, kurang mampu bekerja sama dan kemampuan memahami konsep-konsep biologi rendah.

Berdasarkan permasalahan di atas, maka guru dituntut untuk lebih kreatif dan inovatif dalam merancang pembelajaran 
untuk mencapai kualitas mengajar menjadi lebih baik, sehingga pembelajaran di kelas menjadi hidup dan menyenangkan. Dalam hal ini model pembelajaran yang digunakan oleh guru diharapkan dapat meningkatkan hasil belajar. Selain itu model pembelajaran yang digunakan guru juga diharapkan dapat memberi keadilan bagi peserta didik kelompok bawah maupun kelompok atas. Modelpembelajaran juga diharapkan dapat mengembangkan ketrampilan kerjasama untuk dapat menggali pengetahuan sesama teman secara bebas.

Model pembelajaran kooperatif (Cooperative Learning), yang pada prinsipnya merupakan proses pembelajaran berbasis kerja sama antar peserta didik dan antar komponen-komponen lain di sekolah. Model pembelajaran kooperatif adalah pembelajaran yang berfokus pada penggunaan kelompok kecil peserta didik yang mempunyai tingkat kemampuan berbeda untuk bekerja sama dan memaksimalkan kondisi belajar untuk mencapai tujuan belajar. Dalam menyelesaikan tugas kelompok, setiap anggota saling bekerja sama dan membantu untuk memahami suatu bahan pembelajaran. Jadi, model pembelajaran kooperatif ini cocok digunakan untuk mewujudkan pembelajaran yang berorientasi pada student center. Oleh karenanya, model pembelajaran kooperatif khususnya tipe pembelajaran InsideOutside Circle adalah model pembelajaran dirasa sangat cocok untuk meningkatkan interaksi sosial peserta didik, sehingga hasil belajar meningkat.

Dalam Inside-Outside Circle peserta didik dalam kelas dibagi menjadi dua kelompok besar, masing-masing kelompok besar anggotanya saling berpasangan, sehingga terbentuk pasangan awal untuk mendiskusikan materi atau pertanyaan yang telah diberikan oleh guru. Setelah selesai diskusi dengan pasangan awal, peserta didik berbagi informasi dengan peserta didik dari pasangan awal yang lain dengan bergeser searah jarum jam. Dalam model ini diharapkan peserta didik dapat bekerja sama, dan memiki keberanian serta kemampuan untuk menyampaikan informasi kepada peserta didik yang lainnya. Dari permasalahan di atas, maka untuk dapat meningkatkan hasil belajar peserta didik di SMP Negeri 1 Tamiang Layang, perlu diterapkan model pembelajaran kooperatif yang dapat mengembangkan interaksi sosial sehingga hasil belajar peserta didik meningkat. Dalam hal ini menggunakan model pembelajaran kooperatif tipe InsideOutside Circle.

\section{METODE}

Penelitian tindakan kelas ini dilaksanakan di SMP Negeri 1 Tamiang Layang pada kelas VII B. Satu ruangan kelas sejumlah 28 peserta didik, terdiri atas 16 peserta didik putra dan 12 peserta didik putri.

Waktu pelaksanakan penelitian selama 3 bulan. Penelitian ini dilaksanakan secara bertahap mulai bulan Januari sampai Maret 2017 Adapun urutan waktu pelaksanaan kegiatan penelitian ini dibagi menjadi 3 tahap, yaitu:

1) Tahap Persiapan

Tahap persiapan meliputi: penyusunan proposal. Tahap ini dilaksanakan pada bulan Januari 2017.

2) Tahap Penelitian

Tahap penelitian meliputi semua kegiatan yang berlangsung di kelas untuk pengambilan data. Tahap ini dilaksanakan pada bulan Akhir Januari sampai Akhir Februari 2017.

3) Tahap Penyelesaian 
Tahap penyelesaian terdiri dari analisis data dan penyusunan laporan. Tahap ini dilaksanakan pada bulan Maret 2017.

Bentuk penelitian ini adalah penelitian tindakan kelas (Classroom Action Research) yang dilaksanakan untuk memecahkan masalah di dalam kelas serta mencobakan hal-hal baru demi peningkatan kualitas pembelajaran. Penelitian tindakan kelas ini menggunakan Kemmis dan Robin Mc. Penelitian tindakan kelas terdiri dari 4 tahapan dasar yang saling terkait dan berkesinambungan yaitu perencanaan (planning), pelaksanaan (acting), pengamatan (observing), dan refleksi (reflecting). Keempat tahapan tersebut dalam pelaksanaannya dapat dilihat seperti bagan berikut:

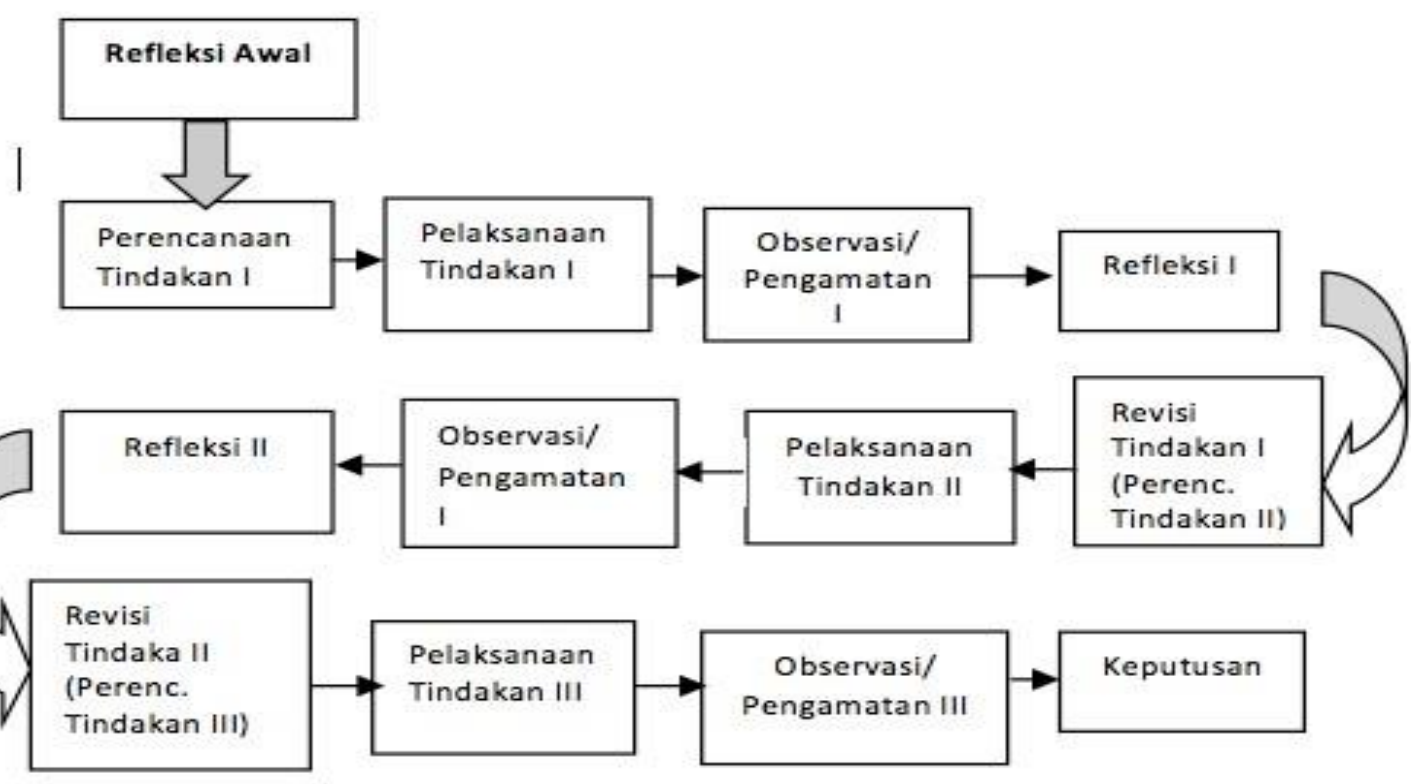

Gambar 1. Bentuk dan Strategi Penelitian Tindakan Kelas

Adapun sumber data dalam penelitian ini antara lain:

1) Hasil observasi kelas pada proses pembelajaran untuk guru dan peserta didik.

2) Hasil ulangan harian.

Teknik yang digunakan dalam pengumpulan data pada penelitian ini meliputi observasi dan dokumen hasil belajar yang masing-masing diuraikan sebagai berikut:

\section{Observasi}

Observasi yang dilakukan adalah observasi berperan pasif yang dilakukan oleh observer (teman sejawat), yang mengambil tempat duduk paling belakang untuk mengamati proses pembelajaran di kelas baik aktivitas guru maupun peserta didik, sehingga peneliti dapat secara leluasa melakukan kegiatan proses belajar mengajar. Observasi dilakukan dengan menggunakan pedoman sebagai instrumen pengamatan proses pembelajaran 
dilengkapi aspek-aspek yang diteliti, sehingga membantu peneliti dalam memfokuskan yang akan diteliti.

\section{Dokumen Hasil Belajar}

Dokumen hasil belajar terdiri dari pretes dan postes (ulangan harian) pada masingmasing subkompetensi dasar.

Indikator keberhasilan pada
pembelajaran ini disesuaikan dengan
Kriteria Ketuntasan Minimal yang telah ditentukan, yaitu 65. Ketuntasan kelas mencapai $75 \%$.

\section{HASIL DAN PEMBAHASAN}

\subsection{Hasil Penelitian}

Data yang terkumpul terdiri atas data hasil belajar pada ranah kognitif dan afektif. Data tersebut diperoleh dari kelas VII B dengan menggunakan model pembelajaran kooperatif tipe Inside-Outside Circle.

Tabel 1. Deskripsi Data Hasil Belajar Ranah Kognitif dan Afektif Peserta Didik

\begin{tabular}{ccccc}
\hline Hasil Belajar & Jumlah Data & Nilai Tertinggi & $\begin{array}{l}\text { Nilai } \\
\text { Terendah }\end{array}$ & Rerata \\
\hline $\begin{array}{c}\text { Ranah } \\
\text { Kognitif } \\
\text { Ranah Afektif }\end{array}$ & 28 & 93 & 45 & 68,35 \\
\hline
\end{tabular}

Dari tabel diatas dapat dilihat bahwa rerata hasil belajar peserta didik pada siklus
I untuk ranah kognitif adalah 68,35 dan untuk ranah afektif adalah 69,14 .

Tabel 2. Distribusi frekuensi hasil belajar peserta didik ranah kognitif Siklus I

\begin{tabular}{cccc}
\hline Interval kelas & Nilai Tengah & Frekuensi & Persentase (\%) \\
\hline $52-59$ & 55.5 & 2 & 7,14 \\
$60-67$ & 63.5 & 12 & 42,85 \\
$68-75$ & 71,5 & 7 & 25,00 \\
$76-83$ & 79,5 & 3 & 10,72 \\
$84-92$ & 88,5 & 3 & 10,72 \\
$93-100$ & 96,5 & 1 & 3,57 \\
\hline & Jumlah & & 28 \\
\hline
\end{tabular}

Ketuntasan hasil belajar ranah kognitif pada siklus II mencapai $96,43 \%$ sebanyak 27 peserta didik dari jumlah peserta keseluruhan 28. Jadi, masih terdapat 1 peserta didik atau $3,57 \%$ yang belum tuntas pembelajarannya pada siklus II. Hal ini disebabkan karena, pada proses pembelajaran guru belum berperan penuh sebagai fasilitator dan perhatian belum merata, sementara peserta didik belum 
semuanya dapat aktif dalam pembelajaran, kurang serius dan kurang konsentrasi. Disamping itu kondisi peserta didik secara keseluruhan mempunyai IQ di bawah peserta didik lainnya.

Tabel 3. Distribusi frekuensi hasil belajar peserta didik ranah afektif Siklus II

\begin{tabular}{cccc}
\hline Interval kelas & Nilai Tengah & Frekuensi & Persentase (\%) \\
\hline $56-64$ & 60 & 1 & 3,57 \\
$65-73$ & 69 & 14 & 50.00 \\
$74-82$ & 78 & 11 & 39,29 \\
$83-91$ & 87 & 2 & 7,14 \\
\hline & Jumlah & 28 & 100,00 \\
\hline
\end{tabular}

\subsection{Pembahasan}

\section{Siklus I}

Pelaksanaan siklus I terdiri dari 2 pertemuan (4X 40 menit), pada pertemuan tersebut menggunakan model pembelajaran kooperatif tipe Inside-Outside Circle. Materi Pada sklus I adalah Klasifikasi Makhluk Hidup (3 Kingdom). Pada awal pembelajaran guru menyampaikan tujuan dan motivasi untuk mempelajari materi tersebut. Penyampaian tujuan dan melalui penyampaian tujuan dan motivasi kepada peserta didik diharapkan peserta didik akan tertarik untuk belajar dan memberikan gambaran materi yang harus dikuasai oleh peserta didik sehingga akan menumbuhkan motivasi untuk mempelajari materi yang akan disampaikan. Tumbuhnya motivasi peserta didik tersebut akan membangkitkan rasa ingin tahu dan keberanian untuk berperan aktif dalam berdiskusi tentang materi yang belum dipahami.

Kegiatan selanjutnya yang dilakukan adalah pengenalan topik dan informasi oleh guru untuk mengantarkan peserta didik pada materi pembelajaran. Kegiatan selanjutnya memasuki tahapan inti dari
Inside-Outside Circle, sebagai berikut : tahap 1: Menyampaikan tujuan dan motivasi, tahap 2: pengenalan topik dan sumbang saran, tahap 3: membagi kelas menjadi 2 kelompok besar, tahap 4: berdiskusi dalam kelompok awal dan kelompok besar, tahap 5: Evaluasi melalui presentasi kelas, tahap 6: pemberian penghargaan, membuat rangkuman.

Hasil belajar biologi peserta didik pada materi Klasifikasi Makhluk Hidup mengalami peningkatan rerata hasil belajar dan ketuntasan belajar. Hal ini dapat dilihat dari rerata hasil belajar ranah kognitif peserta didik pada siklus I adalah 68,35 sedangkan pada siklus II adalah 77,57. Jadi ada peningkatan sebesar 9,22.\%. Melihat ketuntasan belajar dari $56 \%$ menjadi $77,75 \%$ ada peningkatan $21,75 \%$ Dengan demikian ada peningkatan hasil belajar yang signifikan pada penggunaan model pembelajaran kooperatif tipe Inside-Outside Circle pada materi Klasifikasi Makhluk Hidup.

Model pembelajaran merupakan faktor eskternal yang dapat mempengaruhi hasil belajar peserta didik. Merujuk pemikiran 
Joyce dalam bab terdahulu, bahwa model pembelajaran dapat membantu peserta didik dalam memperoleh informasi, ide, keterampilan, cara berpikir, dan mengekspresikan ide. Jadi, untuk mencapai tujuan pembelajaran yang diharapkan model pembelajaran sangat diperlukan, tentunya dengan perencanaan dan pengelolaan sebaik-baiknya. Melalui model pembelajaran kooperatif tipe Inside-Outside Circle dalam pembelajaran biologi pada materi Klasifikasi Makhluk Hidup, hasil belajar peserta didik meningkat. Hal ini terjadi karena peserta didik dalam proses pembelajarannya melakukan keterampilan proses sains melalui pengamatan dilingkungan sekolah maupun rumah, pengukuran hasil eksperimen, memecahkan masalah yang sudah diterimanya, dan bertanya/merespon pendapat teman. Melalui kegiatan tersebut, keterampilan proses sains sebagai karakteristik pembelajaran biologi dapat muncul dan menghasilkan pengalaman belajar yang berarti pada diri peserta didik sehingga akan berdampak positif terhadap hasil belajar peserta didik.

Sesuai dengan teori belajar Peaget, bahwa perkembangan kognitif sebagian besar bergantung pada seberapa besar anak aktif memanipulasi dan aktif berinteraksi dengan lingkungannnya. Dalam proses pembelajaran peserta didik melakukan pengamatan langsung dilingkungan sekolah, sekitar rumah, dan eksperimen sehingga peserta didik memiliki bekal untuk belajar berkelompok dalam model pembelajaran kooperatif. Jadi, melalui model pembelajaran kooperatif tipe Inside-Outside Circle tepat untuk meningkatkan hasil belajar peserta didik pada pembelajaran biologi materi Klasifikasi Makhluk Hidup. Pada penilaian ranah afektif melalui pengamatan sikap kooperatif pada dasarnya mengalami peningkatan walaupun dengan prosentase yang rendah.

Keadaan seperti ini tidak terlepas dari bagaimana mengelola pembelajaran kooperatif yang diharapkan. Sikap kooperatif peserta didik dalam pembelajaran kooperatif baik tipe InsideOutside Circle apabila dikelola sesuai prosedur yang sudah ditentukan maka sikap dan perilaku peserta didik dapat terarah dan dapat memberikan kontribusi yang positif dalam proses pembelajaran. Karena melalui sikap kooperatif peserta didik akan memiliki kemampuan bicara yang pokok (inner speech) yang dapat digunakan sebagai alat berpikir. Walaupun dalam penelitian ini model pembelajaran kooperatif belum dapat dilaksanakan secara maksimal.

Pembelajaran kooperatif tipe InsideOutside Circle ini, memiliki keunggulan dan kelemahan. Adapun keunggulan dari InsideOutside Circle adalah peserta didik akan lebih bertanggung jawab akan tugasnya, berusaha untuk bisa bekerja sama dengan sesama teman dan terfokus, berusaha untuk bisa menyampaikan informasi dengan baik, secara individu maupun kelompok dapat mencapai kompetensi yang diharapkan, memperoleh reward yang membanggakan. Proses dari metode ini akan membawa dampak yang besar bagi peserta didik untuk pembelajaran dan kehidupan selanjutnya.Apabila penggunaan tipe insideOutside Cirkle ini belum dikelola dengan baik, maka akan memiliki kelemahan yaitu adanya kegaduhan sehingga mengganggu konsentrasi peserta didik yang lain.

\section{Siklus II}

Pada siklus II terdiri dari 2 pertemuan (6 x 40 menit) pada materi Klasifikasi Makhluk Hidup (2 Kingdom). Berdasarkan 
hasil observasi guru dan peserta didik dalam pembelajaran biologi, peningkatan hasil belajar dalam pembelajaran biologi telah ditunjukkan pada siklus I, tetapi belum sepenuhnya dapat memenuhi kriteria yang diharapkan. Ketuntasan belajar pada siklus I hanya mencapai $75,67 \%$. Dalam rangka mencapai persentase capaian target $80 \%$, maka dilakukan tindakan untuk siklus berikutnya. Dengan melihat berbagai kendala yang dihadapi pada siklus I, maka dilakukan upaya perbaikan pelaksanaan tindakan pada siklus II yang diharapkan dapat meningkatkan hasil belajar agar mencapai persentase capaian target yaitu: a) Penyusunan rencana pembelajaran sesuai dengan refleksi siklus I; b) Adanya efektivitas waktu untuk setiap langkah pembelajaran; c) Guru harus menciptakan suasana menjadi lebih akrab dan hangat, sehingga peserta didik merasa nyaman dan tidak tegang; d) Guru mewajibkan masingmasing kelompok mempunyai perwakilan untuk bertanya kepada kelompok lain dan pada akhir pertemuan masing-masing kelompok diberi tugas mengumpulkan materi dan pertanyaan yang diajukan oleh peserta didik lain selama presentasi kelompok berlangsung; e) Peserta didik ditugasi untuk membaca di rumah tentang materi yang akan dipelajari pada pertemuan selanjutnya; f) Pada kegiatan tatap muka dengan guru khususnya saat menyajikan materi belum banyak peserta didik yang berani bertanya. Hal ini disebabkan guru kurang berinteraksi dengan peserta didik dalam pembelajaran.

Adanya pembatasan waktu saat kerja kelompok pada siklus II juga mengakibatkan setiap anggota kelompok terlibat aktif agar dapat menyelesaikan tugasnya tepat waktu sehingga dituntut berpartisipasi aktif dalam menyumbangkan gagasan. Dengan demikian terjadi komunikasi aktif di antara para anggota kelompok dalam kegiatan berdiskusi. Akibatnya semua peserta didik aktif terlibat secara langsung dalam proses pembelajaran. Pembelajaran aktif (active learning) juga dimaksudkan untuk mengoptimalkan penggunaan semua potensi yang dimiliki oleh peserta didik, sehingga peserta didik dapat mencapai hasil belajar yang memuaskan sesuai dengan karakteristik pribadi yang mereka miliki. Di samping itu pembelajaran aktif (active learning) juga dimaksudkan untuk menjaga perhatian peserta didik agar tetap tertuju pada proses pembelajaran. Hal ini sesuai dengan teori belajar Peaget dimana perkembangan kognitif bergantung kepada seberapa besar anak aktif memanipulasi dan aktif berinteraksi dengan lingkungannya.

Dalam siklus II diperoleh hal-hal sebagai berikut: a) Kemampuan guru menerapkan langkah-langkah pembelajaran dan mengelola waktu pembelajaran sudah lebih meningkat dibandingkan siklus I; b) Peserta didik yang berani bertanya saat guru menyajikan materi maupun saat presentasi dan diskusi meningkat jumlahnya dibandingkan dengan siklus I; c) Peserta didik lebih berani bertanya saat diberi kesempatan oleh gurunya untuk bertanya mengenai materi yang belum dipahaminya; d) Kegiatan presentasi berjalan baik, hal ini dipengaruhi penugasan guru untuk mempelajari materi sebelumnya.

Atas dasar hasil refleksi siklus II dapat diketahui bahwa terjadi peningkatan aktivitas maupun hasil belajar biologi telah mencapai target yang telah ditentukan, sehingga tidak perlu dilakukan siklus berikutnya. Selama penerapan tindakan terjadi peningkatan hasil belajar baik pada siklus I maupun siklus II. Jika dibandingkan hasil observasi antara prasiklus, siklus I, 
dan siklus II untuk hasil belajar biologi dengan menggunakan pembelajaran kooperatif tipe InsideOutside Circle yaitu diperoleh ketuntasan belajar berturut-turut adalah $46 \%, 75,67 \%$, dan $81,08 \%$.

\section{KESIMPULAN}

Penggunaan model pembelajaran kooperatif tipe Inside-otside Circle meningkatkan hasil belajar biologi pada materi Klasifikasi Makhluk Hidup. Peserta didik dalam pembelajaran biologi dengan model pembelajaran kooperatif tipe Insideoutside Circle memperoleh rerata hasil belajar lebih baik yaitu 68,35 pada siklus I dan 77,21 pada siklus II.

\section{Referensi}

Aunurrahman.2009. Belajar Dan Pembelajaran. Bandung : Penerbit Alfabeta.

Agus Suprijono. 2009. Cooperative Learning. Yogyakarta : Pustaka Pelajar.

Anita Lie. 2008. Cooperative Learning Mempraktikkan Cooperative Learning Di Ruang-Ruang Kelas. Jakarta : Penerbit PT Gramedia Widiasarana

Indinesia.

Baharuddin dan Esa Nur W.. 2010. Teori Belajar dan Pembelajaran. Jogjakarta : ArRuzz Media

Bermawi Munthe. 2009. Desain Pembelajaran. Yogyakarta : Pustaka Insan Madani.

Campbell, Reece Michell.. 2000. Biologi Jilid I. Jakarta : Erlangga.

Daryono.2010. Belajar dan Mengajar. Bandung : CV.Yrama Widya.
Hanafiah dan C. Suhana.2009.Konsep Strategi Pembelajaran. Bandung: PT Refika Aditama.

Haryati,Mimin. 2007. Model dan Teknik Penilaian pada Tingkat Satuan Pendidikan.

Jakarta: Gaung Persada Pers.

Isjoni. 2009. Pembelajaran Kooperatif. Yogyakarta: Pustaka Pelajar.

Johnson,David W.Johnson, Roger T. Johnson, Edythe Johnson Halubec..2010. Colaborative Learning. Bandung: Penerbit Nusa Media.

Lif Khoiru Ahmadi, Sofan Amri. 2010. Strategi Pembelajaran Sekolah Berstandar Internasional dan Nasional. Jakarta : PT.Prestasi Pustakaraya

Masidjo.2006. Penilaian Pencapaian Hasil Belajar Siswa di Sekolah. Yogyakarta

Penerbit Kanisius.

Muhammad Asrori. 2008. Psikologi Pembelajaran. Bandung : CV.Wacana Prima.

Mutiara Indah. 2004. Mekanisme Kerja Hormon. Medan : USU Digital Library

Nana Sudjana.1995. Penilaian Hasil Proses Belajar Mengajar. Bandung: PT Remaja Rosdakarya.

Nasution. 2008. Berbagai Pendekatan dalam Proses Belajar Mengajar. Jakarta : PT Bumi Aksara.

Paul Suparno.2001. Teori Perkembangan Kognitif Jean Piaget. Yogyakarta :

Penerbit Kanisius. 
Paul Suparno.2006. Filsafat Konstruktivisme dalam Pendidikan. Yogyakarta :

Penerbit Kanisius.

Purwanto.2009. Evaluasi Hasil Belajar. Yogyakarta: Pustaka Pelajar.

Ratna Willis Dahar. 1989. Teori-Teori Belajar. Bandung : Penerbit Erlangga.

Susilo, Herawati. 2000. Kapita Selekta Pembelajaran Biologi. Jakarta : Penerbit Universitas Terbuka.

Slavin, Robert E. 2010. Cooperative Learning. Bandung: Penerbit Nusa Media.

Wartono dkk. 2004. Sains. Jakarta : Departemen Pendidikan Nasional .

Wenno I.H. 2008. Strategi Belajar Mengajar Sains Berbasis Kontekstual. Yogyakarta : Penerbit Inti Media.

Zaenal Arifin.2009. Evaluasi Pembelajaran.Bandung: PT Remaja Rosdakarya. 